\title{
Analysis of credit indebtedness of public companies founded by the City of Loznica
}

\section{Анализа кредитне задужености јавних предузећа чији је оснивач град Лозница}

\author{
Pavle Jakšić \\ PhD Student, University of Novi Sad, Faculty of Economics in Subotica, Republic of Serbia, \\ pavlej236@gmail.com
}

\begin{abstract}
In contemporary business conditions, that is, in a market economy, business success of a company has to be based on a basic economic and business principle of accomplishing the best possible business results with as little investments as possible. Considering that public utilities carry out public interest activities and employ a large number of people in Serbia, a need emerges to analyze their current status. The goal of this business analysis is to find out appropriate ways of improving public utilities business, including the improvement of the entire public utilities sector in Serbia. The subject of this paper is the analysis of indebtedness of public utilities on the territory of the city of Loznica. Special attention is paid to enterprises that have long-term liabilities in their business. The aim of this paper is a realistic presentation of the indebtedness of public utilities whose founder is the City of Loznica. The amount of indebtedness of local companies is compared in relation to the average indebtedness of public companies from the territory of the Republic of Serbia and the Mačva District. The City of Loznica has established five public companies, with three public companies performing communal activities. The paper will use the ratio analysis of financial indicators. The business operations of the utilities in the period from 2017 to 2019 will be analysed. In addition, the aim of this paper is to present alternative sources of financing for public utilities, which companies can use in case of facing financial problems. The research established that public utilities in Loznica do not have high long-term liabilities, but that this is not the case with other public utilities in Serbia.
\end{abstract}

Keywords: public companies, financial analysis, ratio indicators, indebtedness.

JEL classification: G20, G28, H41

Сажетак: У савременим условима пословања, у условима тржишне економије, пословни успех предузећа мора се заснивати на основном економском и пословном начелу остварења што бољих пословних резултата уз што мање улагање. С обзиром да локална јавна предузећа обављају делатност од општег интереса и да упошљавају велики број грађана Србије, јавља се потреба за анализом њиховог тренутног стања. Циљ анализе пословања свакако јесте проналажење одговарајућих начина за побољшање њиховог пословања, а самим тим и унапређење укупне области јавних предузећа у Србији. Предмет овог рада јесте анализа задужености јавних предузећа на територији града Лознице. Посебан осврт је на предузећа која у свом пословању бележе високе дугорочне обавезе. Циљ рада јесте реалан приказ задужености јавних предузећа чији је оснивач Град Лозница. Упоређује се висина задужености локалних предузећа у односу на просек задужености јавних предузећа са територије Републике Србије и мачванског округа. Град Лозница, основао је пет јавних предузећа, с тим што три јавна предузећа обављају комуналну делатност. У оквиру рада користиће се рацио анализа финансијских показатеља. 
Анализира се пословање предузећа у временском периоду од 2017. до 2019. године. Осим тога, циљ рада јесте и приказивање алтернативних извора финансирања јавних предузећа, које предузећа могу искористити у случају суочавања са финансијским проблемима. Истраживањем је утврђено да јавна предузећа у Лозници немају високе дугорочне обавезе, али да то и није случај са осталим јавним предузећима у Србији.

Кључне речи: јавна предузећа, финансијска анализа, рацио показатељи, задуженост. JEЛ класификација: G20, G28, H41

\section{Introduction}

With regard to the significance of the objectives set before public entities and nature of the work they perform it is required to know the organizational structure of the entity, that is, all aspects of good governance and management. With the analysis of all aspects of business operations it is possible to perceive to what extent a company is capable to accomplish defined goals of its existence. A statement is often drawn that public companies represent nowadays a break on further progress of Serbia, that they are prone to producing only losses, making a burden for the state or local self-government budget. In order to know the real state of play in public entities it is necessary to analyze all segments of business operations and functioning of a company in accordance with the fact that only with analytical approach real situation and potential, which public companies in Serbia are disposed of, a conclusion can be reached. Most often activity entrusted to public companies in Serbia is utility activity; however, there are also other fields of activities performed by the public entities.

According to Kaplan \& Norton, 1996: "When designing a system for measuring performance, both financial and non-financial indicators are taken into account". An effective system for measuring performances enables a company to control, monitor and measure its accomplishments in accordance with a defined strategy adequately and promptly (Domanović, 2013). Financial analysis represents a financial management tool which covers a company's financial performance evaluation (Fabozzi \& Peterson, 2003). It involves researching past and present financial data in order to evaluate performance and assess future risk and potential (Shim, 2008). Business efficiency, customer and employee satisfaction resemble non-financial indicators, which are not possible to represent using quantitative units of measure. We can present financial indicators in the form of ratio numbers, i.e. relation between two or more economic values. Neely, Gregory \& Platts, (1995) point out: "Indicators for measuring performance represent a set of metrics, which enables quantitative measuring of efficiency and effectiveness“. Performance appraisal through financial statement analysis is based on past data and conditions from which it is not easy to extrapolate future expectations. However, any decision made based on such a performance assessment can only have an impact on the future (Helfert, 2001). Different views can be found in literature in the definition, significance, and categorization of individual ratios (White et al., 2003). In the basic financial indicators of a company, we can classify indicators of profitability, economy, cost efficiency, indebtedness, and liquidity. 


\section{Literature review}

Each book that deals with ratio analysis contains a different set of ratios, or at least a seemingly different set, primarily because financial indicators appear under different names, calculation methods, and definitions. In this regard, there are as many classifications as there are authors who deal with this analysis.

Also, there is not a uniquely accepted ratio list, nor a standard method of its calculation. During the research, we can encounter variations both in terms of selection and in terms of their method of calculation (Atrill, 2006). The concepts and terminology themselves are not of a universal character and definition (Stead, 1995). Atrill (2006) points out that the financial ratio is the most important ratio when analysing the business of a company. This author points out the significance of its usage during examination of different aspects of financial positions and performance of a single company. In addition, its application is important in long-term planning and control. Financial ratios are used to compare the risks and returns of different companies, all with the goal of making smarter decisions (White et al., 2003). Evans (2000) points out that monitoring the value of financial ratios is the basis for forming an optimal business system in a company. Ratio analysis is one of the most important financial analysis tools. This analysis is considered to be the most popular and most widely used during the analysis of the company's financial performance (Berstein \& Wild, 1999). Many empirical studies have shown that ratio analysis directs company management toward achieving long-term goals and assists in short-term decision-making (Walsh, 2008). The ratio analysis of current and past performance of companies provides a basis for predicting future performance, which is a necessary starting point for further financial considerations of the company (valuation, credit analysis, merger analysis and acquisition) (Palepu et al., 2004). Eliott \& Elliot (2006) point out that financial ratios identify irregularities, anomalies and surprises which require further examination in order to evaluate the financial position of a company. Erić (1992) claims that for one company it is extremely important to choose adequate sources of financing and that the choice of one source entails a large number of mutual factors that can affect the further business of the company (Erić, 2003). The most developed organizational systems have the best funding mechanisms (Mishkin \& Eakins, 2006). Elia (2006) points out that long-term sources of financing can leave significantly bigger consequences to the business of a company. Every company management should strive to establish an optimal structure for the use of borrowed and own funds (Damodaran, 2001; Kaplan \& Anderson, 2007; Fleisher \& Bensoussan, 2000; Brealey et al., 2010).

\section{Methodology and data}

The forthcoming analysis deals with determining the level of indebtedness of public utilities whose founder is the city of Loznica. By calculating the debt ratio for each observed company, we want to show which companies have potential problems with high debts. The data used in calculating these ratios were taken from the balance sheets and income statements of public enterprises. During the analysis, the remarks made in the 
Independent Auditor's Report were also taken into account. The analysis covers the period of three years from 2017 to 2019. Data used in the analysis was taken from the website of Agency for Business Registers. In addition, for the purposes of comparative analysis of the city of Loznica with other municipalities, data from the website of the Republic Secretariat for Public Policies was used. When calculating the mentioned ratios, the methodology explained in the book Analysis of Financial Statements (Rodic et al., 2017) was used. In the listed literature, each debt ratio is defined individually, with an indication of the way in which each of them is calculated. For a comparative analysis of the indebtedness of public companies in the city of Loznica in relation to other local governments, the calculation methodology displayed on the website of the Republic Secretariat for Public Policies, defined by the Ministry of Finance of the Republic of Serbia, was used.

\section{Strategic approach of providing financial resources as an important factor for business of a company}

Financing is an important factor ensuring survival and efficiency of business in every company. The importance of adequate sources of financing is not in question even when it comes to public entities. Public entities, just as any other entity, have a need for investing in human capital, new facilities, new equipment, providing new services and everything is conditioned by the possibility of a company to satisfy the needs for adequate sources of financing. The choice of right sources of financing for every entity represents a very important question and decision on the manner in which some capital entrepreneurship will be financed or some facility has a strategic significance for the management of an entity (Erić, 1992).

Financing certainly represents one of the biggest problems faced by public entities in Serbia. In most cases, the decision on financing entails a series of other decisions, both financial and business ones (Erić, 2003). With regards to the high level of interdependence and conditionality among different types of decisions, on the occasion of making decisions, at least two economic areas emerge and intersect (financial and strategic management). Only developed systems have adequate and well-developed mechanisms of indirect financing (Mishkin \& Eakins, 2006).

A special problem with public entities is that there often emerges a need for financing new investments that companies cannot meet on their own (Erić et al., 2011). In the very approach of classifying different sources of financing, some general division of sources of financing is to short-term and long-term sources. Short-term sources of financing are those sources that by definition have maturity period less than a year (payables due to suppliers, short-term loans, issued short-term securities, etc.). Long-term sources of finance have a greater significance for a public company according to the fact that they can have a significantly higher impact on the liquidity and long-term financial stability of a company. Not only do they affect financial stability of a company, but they also maintain the structure of a company's capital (Elia, 2006). 
In practice, loaned resources should have lower expenditures, but it has to be taken into account that the very quantity of resources is linked to creditworthiness of an entity, which entails a higher degree of risk that the resources will not be returned in the agreed time frame with previously defined reimbursement. Every entity's management should set up an optimum level of using loaned and their own resources, comprising and analysing financial capacity and the ability of the entity (Damodaran, 2001). The important factor in making investment decisions of an entity's management is the level of average weighted capital costs. What should be mentioned is a modern model of costs management on the bases of activities, which implies costs allocations by activities and also monitors costs movements per individual activity or a part of production process and allocates them based on certain time equations (Kaplan \& Anderson, 2007). In the process of identifying model of costs management, we should take care of the information spectrum of a method, focus and the volume of tasks, as well as information, organizational and other resources of the management process (Fleisher \& Bensoussan, 2000). If we look at previously mentioned optimal structure of a capital, based on which a company establishes optimum structure of its own and loaned sources of resources, in theory, it is established in a situation when the capital costs are at the lowest possible level. Although it is more about theoretical and not about practical concept, calculating this indicator can represent an important factor on the occasion of determining adequate sources of financing an entity. In order to determine average weighted costs of a capital it is necessary to be aware of each and every source of finance, as well as their proportion during their usage (Brealey et al., 2010).

\section{Analysis of financial statements - ratio analysis}

In order for an enterprise to efficiently govern itself, it is necessary to calculate goals for a certain time period. The inability to measure certain performances would mean to some extent wandering in the dark, without indications of clear problems in the company's operations. One way to establish an appropriate system based on financial performance measures is to use ratio analysis (Evans, 2000).

Ratio is a mathematical relation between two values, and financial ratio is a relation between two financial positions (Fabozzi \& Peterson, 2003). The ratio simply relates one position of the financial report to another position or to some business resource (Evans, 2000). Ratio analysis gives information about a certain situation in which certain enterprise finds itself (Bernstein \& Wild, 1999). The choice of specific ratio indicators directly depends on the strategy implemented by one company (Hagos \& Pal, 2010). By relating certain positions in financial statements, a large number of ratios can be calculated, but the point is to know which ratio provides which information (Elliot \& Elliot, 2006). By calculating certain number of ratios it is often possible to get good picture about financial positions and performance. Ratios are what can indicate financial strengths and weaknesses, and that is why they are often used by those interested in the company's business and performance (Atrill, 2006). The information that can be obtained by calculating the mentioned ratios refers to the company profile, economic characteristics, competitive strategies and unique financial and investment characteristics (White et al., 2003). 
Steps which are needed to be done during the ratio analysis creation are (Bernstein \& Wild, 1999):

- defining analysis goals explicitly;

- formulating specific questions and criteria;

- identifying the most effective and the most efficient indicators;

- results interpretation.

The usefulness of the obtained values of the ratio indicators depends directly on the business aspects of the company which is the subject of examination (Elliot \& Elliot, 2006). Three key factors influence the value of ratio indicators, and they should be taken into account when interpreted (White et al., 2003). The first factor is strategy management. An enterprise can decide to implement the strategy: high turnover / low margin or low turnover / high margin. Choosing one of these strategies can affect the values of certain financial indicators. The second important factor is the characteristic of the activity in which one enterprise is engaged. The values of individual indicators are also influenced by the characteristics of the activity in terms of competitiveness (Selling \& Stickney, 1989). Life cycle of a product is the third important factor which can affect the value of ratio indicator. It was found that in the inception phase, the company has high activity indicators, but low liquidity, profitability and solvency indicators (Savič \& Thomson, 1978).

Ratios become important analysis tool for enterprise performance when they are compared to (Shim, 2008):

- values of the same ratio for the same enterprise in the past;

- some predefined standard;

- ratio of other enterprises from the same industry;

- ratios for the business in which enterprise operates.

\section{Content of ratio indicators of indebtedness of observed public entities, empirical analysis and discussion}

When analysing financial indicators, it should be borne in mind that all financial indicators have many common elements, because they are all derived from the elements of financial statements. They are often interconnected and can be viewed as a system (Helfert, 2001). Level of indebtedness of public utilities founded by the city of Loznica will be considered in the upcoming analysis. In order to consider the level of indebtedness of public utilities, it is necessary to analyze the following 4 indicators of indebtedness for all observed public utilities (Rodić et al., 2017):

1. financial leverage;

2. coefficient of their own financing;

3. indebtedness factor;

4. indicator of the independence of financing.

Indebtedness indicators can be viewed as indicators of business security. The reason for calculating and analysing these four indebtedness indicators is to determine business 
security of the public enterprises in the period from 2017 to 2019. By presenting possible high values of certain indicators, the potential problems that companies have with the amount of debt would be pointed out. Financial leverage represents the ratio of total sources of fund and own sources. The financial leverage ratio measures the riskiness of investing in a company and is an indicator of possible corporate borrowing. Financial leverage speaks to how large a company's asset base in comparison to its own capital. It is also called the equity multiplier (Fabozzi \& Peterson, 2003). Financial leverage allows a company to own more than the value of its equity. It can directly affect the increase in the rate of return on the company's own funds, as long as the price of borrowed capital is lower than the return that this capital brings (Palepu et al., 2004). As a rule, the company should strive to keep this coefficient as low as possible. The larger the share of funds financed by equity, the lower the financial leverage (Bernstein \& Wild, 1999).

Ratio of self-financing shows percentage share of a company's own capital in its total business operations. Referential value of this indicator is 0.5 and higher, which means that this ratio should not be less than 0.5 . If the value of this indicator is 0.5 , then the share of self-financing in a company is 50\%. Value of this indicator is in a direct relation with degree of risk for investing a certain enterprise (a higher value of this ratio is desired). This ratio has broad application in corporate finances and is used as a test of financial strength and a position of an enterprise (Marr, 2012). High value of this ratio is especially problematic for enterprises which have cash flow problem, especially in crises (Shim, 2008).

Indebtedness factor measures the relationship between liabilities and money flow and shows how many years it would take to settle all debts with the use of realized money flow, with the assumption of restraining from investments and sharing the gain. Referential value is 5 years, which means that an entity is facing huge debts if it succeeds in settling liabilities in defined deadline. The essence is in a good balance of debt and equity use, so that profit is maximized, while managing risk (Evans, 2000).

The indicator of the independence of financing measures the ratio of own and other's sources in the in the total sources of financing. According to traditional rule of financing, this ratio should be $50 \%$ of own and $50 \%$ of other's sources of financing. According to organic composition of capital, this ratio should be $60 \%$ of own and $40 \%$ of others' capital. Creditors usually look at this indicator when deciding whether to approve long-term funding sources (Bernstein \& Wild, 1999).

In the literature of a business analysis and measuring of an entity's efficiency, based on financial reports, a prominent place is taken up by the instruments of financial analysis. Kothari \& Barone (2012) emphasize "three basic tools (instruments) of financial analysis: (1) horizontal analysis (report on trends); (2) vertical analysis, and (3) financial indicators “. Horne \& Wachowich (2007) state: "In order to assess financial state of play and success of an entity's business, financial analyst has to check various aspects of corporation's health. An instrument that is often used during these checks is financial ratio or index, which connects two financial data by dividing one quantity by the other ". 
The analysis comprises business operations of five public companies, the founder of which is the city of Loznica, in the time period between 2017 and 2019:

1) Public utility company "Water Supply and Sewerage" - Loznica;

2) Public utility company "Our Home" - Loznica;

3) Public utility company for the production and distribution of thermal energy "Heating Plant" - Loznica;

4) Public company "Loznica Development" - Loznica;

5) Public utility company "Parking Service" - Loznica.

Table 1. Indebtedness indicators - Public utility company "Water Supply and Sewerage" - Loznica (2017-2019)

\begin{tabular}{|c|l|c|c|c|}
\hline No. & Ratio indicators of indebtedness & $\mathbf{2 0 1 7}$ & $\mathbf{2 0 1 8}$ & $\mathbf{2 0 1 9}$ \\
\hline 1. & Financial leverage & 1.3991 & 1.3872 & 1.2228 \\
\hline 2. & Ratio of self-financing & 0.417989 & 0.428754 & 0.448270 \\
\hline 3. & Indebtedness factor & 16.8871 & 13.0374 & 11.6793 \\
\hline 4. & Indicator of financing independence & 0.4168 & 0.4283 & 0.4499 \\
\hline
\end{tabular}

Source: Calculation and layout of the author based on the data of the Business Registers Agency

Financial leverage ratio does not have a specifically defined referential value, but it is pointed out in literature that an enterprise should have low value of this ratio. If we look at the value of this ratio at "Water Supply and Sewerage" PUC, we will see that the value decreases from year to year. However, the very value of this ratio is problematic, and the key reasons are high debts this company faced in the period between 2017 and 2019. Based on the gained value of the coefficient of self-financing we can notice that its value increases over years. However, the key reason for the increase in the values of this indicator is not the increase in the basic capital but the decrease in the value of total assets. Since the value of the ratio in all three observed years is below 0.5 , we can conclude that the risk degree for investing in this entity is at a high level. The value of indebtedness factor with observed entity is significantly above the defined referential value. The key reasons for this are high debts the entity is facing. It should be noted that observed entity got into a credit debt in 2008 and that the loan principal repayment is still in progress, as well. The good thing for the entity is that this rate gets reduced over years and the key reason for this is that the entity succeeds in continuously reducing the total liability. Based on obtained values of indicators of financing independence we can see that the entity is financed with more than $50 \%$ from others' sources, which is not a good indicator for this entity. A good fact is that this indicator marks an increase of values over years, primarily all owing to the increase in their own sources.

Table 2. Indebtedness indicators - Public utility company “Our Home”- Loznica (2017-2019)

\begin{tabular}{|c|l|c|c|c|}
\hline No. & Ratio indicators of indebtedness & $\mathbf{2 0 1 7}$ & $\mathbf{2 0 1 8}$ & $\mathbf{2 0 1 9}$ \\
\hline 1. & Financial leverage & 0.1695 & 0.1717 & 0.1780 \\
\hline 2. & Ratio of self-financing & 0.791434 & 0.793163 & 0.746430 \\
\hline 3. & Indebtedness factor & 1.3493 & 1.4344 & 1.3442 \\
\hline 4. & Indicator of financing independence & 0.8550 & 0.8535 & 0.8489 \\
\hline
\end{tabular}

Source: Calculation and layout of the author based on the data of the Business Registers Agency 
Financial leverage with this observed entity is significantly lower in comparison to the previous entity. The key reason for it is that this entity does not have high debts. By observing the very structure of the entity's debt it can be seen that short-term liabilities prevail, which indicates that the entity does not have high credit indebtedness. Negative phenomenon is that the values of this indicator in the observed period increase and the reason for it is a mild increase in total liabilities of the entity. With the observed entity, equity is dominant in the total business of the company with more than $75 \%$. When this indicator is observed, the attention should be paid to the decrease in value in 2019 in comparison to 2017 and 2018, and it should be noted that the reason for this decrease is the enlargement of the total assets in analysed year. The indebtedness factor of this entity is significantly below the referential value. This indicator tells us that the entity has the ability to settle its obligations for less than a year and a half. The indicator of financing independence is above the referential value, which indicates that, in the total source of financing, own sources used by the entity dominate with $85 \%$ in 2017 and 2018. In 2019, a mild decrease in the value of this indicator was marked.

Table 3. Indebtedness indicators - Public utility company "Heating Plant"-Loznica - Loznica (2017-2019)

\begin{tabular}{|c|l|c|c|c|}
\hline No. & Ratio indicators of indebtedness & $\mathbf{2 0 1 7}$ & $\mathbf{2 0 1 8}$ & $\mathbf{2 0 1 9}$ \\
\hline 1. & Financial leverage & 2.2613 & 2.4782 & 2.4220 \\
\hline 2. & Ratio of self-financing & 0.303310 & 0.316220 & 0.308430 \\
\hline 3. & Indebtedness factor & 18.8862 & 85.4916 & 27.7277 \\
\hline 4. & Indicator of financing independence & 0.3066 & 0.2855 & 0.2922 \\
\hline
\end{tabular}

Source: Calculation and layout of the author based on the data of the Business Registers Agency

The analysed entity in observed time period marks significantly high values of the coefficient of financial leverage. The reason for it is that the entity marks significantly high total liabilities in the observed period of time. If the structure of obligations is observed, it can be seen that first of all short-term liabilities dominate, such as liabilities due to suppliers. Coefficient of its own financing is at an extremely low level. Even though its value increased slightly in 2018 and 2019, there is another drop in the value of this indicator. With the observed indicator, the attention should be paid to the report of an independent auditor, who indicates the need of repeated assessment of the entity's capital. The highest factor of indebtedness with public utility company "Heating Plant" is marked in 2018. The reason for extremely high value of this indicator in that year is the loss faced by the entity. The entity managed to recover from the loss and in 2019 it operates with profit of 12,861,000.00 dinars, which affected the drop in this indicator at the same time. In 2018 and 2019, the entity was financed with less than $30 \%$ from its own sources of financing. Such low value tells us that the entity has big problems in the structure of its own and other sources and that the risk of investment in observed entity is extremely high.

Table 4. Indebtedness indicators - Public utility company "Parking Service" - Loznica

\begin{tabular}{|c|l|c|c|c|}
\hline No. & Ratio indicators of indebtedness & $\mathbf{2 0 1 7}$ & $\mathbf{2 0 1 8}$ & $\mathbf{2 0 1 9}$ \\
\hline 1. & Financial leverage & 0.0431 & 0.0398 & 0.0271 \\
\hline 2. & Ratio of self-financing & 0.317038 & 0.273913 & 0.258371 \\
\hline 3. & Indebtedness factor & 0.0614 & 0.0535 & 0.0360 \\
\hline
\end{tabular}




\begin{tabular}{|c|c|c|c|c|}
\hline 4. & Indicator of financing independence & 0.9587 & 0.9617 & 0.9736 \\
\hline
\end{tabular}

If we perceive the total debts the entity had in the period between 2017 and 2019, we can see that the entity does not have problems with repayment of short-term and long-term liabilities. Based on that, the entity marks extremely low values of the coefficient of financial leverage, with continuous drop in its value over years. As for ratio of selffinancing, the analysed entity's own financing is below defined referential value. It is important to emphasize that the reason for such a low value of observed ratio in the basic capital, which is 5,000,000.00 dinars (it does not change in the observed period). Of course, on the occasion of this particular analysis what should be taken into account is the field of activity the entity is involved in. Like financial leverage, indebtedness factor is also at an extremely low level indicating that the entity can settle its liabilities from the money flow in less than a month. The indicator of the financing independence is at an extremely high level, which is to a certain extent a rare phenomenon when it comes to a public entity. In the total financing sources, own sources are dominant, exceeding $95 \%$.

Table 5. Indebtedness indicators - Public company "Loznica Development - Loznica

\begin{tabular}{|c|l|c|c|c|}
\hline No. & Ratio indicators of indebtedness & $\mathbf{2 0 1 7}$ & $\mathbf{2 0 1 8}$ & $\mathbf{2 0 1 9}$ \\
\hline 1. & Financial leverage & 0.0549 & 0.1984 & 0.1272 \\
\hline 2. & Ratio of self-financing & 0.786593 & 0.732866 & 0.709458 \\
\hline 3. & Indebtedness factor & 0.3782 & 0.9198 & 0.5951 \\
\hline 4. & Indicator of financing independence & 0.8928 & 0.9172 & 0.8872 \\
\hline
\end{tabular}

Source: the author's calculation and layout based on the data of the Business Registers Agency

Based on the received values of financial leverage in the observed year, we can conclude that the entity, as well as the previously analysed, has a possibility of indebtedness (due to low liabilities). The risk of investment in observed entity is at a low level and the debt principal gets reduced in years. The value ratio of self-financing in all three years tells us that in the entity, its own capital is dominant in the total business of the entity with more than $70 \%$. The drop of this indicator was marked in 2018 and 2019 in comparison to 2017, primarily due to the drop in value of the total assets of the entity. The value of the indebtedness fluctuates over the observed period of time. The highest value was marked in 2018, when there was a leap in total liabilities in comparison to 2017 with a slight drop in retained earnings. The good fact is that the value of the indicator dropped in 2019 , that is, the entity managed to settle a part of short-term and long-term liabilities. The entity finances its operations with more than $85 \%$ from its own sources of financing. The entity marks an increase in the value of this indicator in 2018 in comparison to 2017, so that in 2019 there would be another drop in value of this indicator to $88 \%$.

For a more comprehensive comparative analysis of the indebtedness of public utility companies from the territory of the city of Loznica, in comparison to public utility companies of local self-governments units, net debt indicator/EBITDA is taken into account. 
Graph 1. Comparison of net debt/EBITDA of public utility companies on the territory of the city of Loznica in the period between 2015 and 2019 with the average of all self-government units and the average of Mačva District

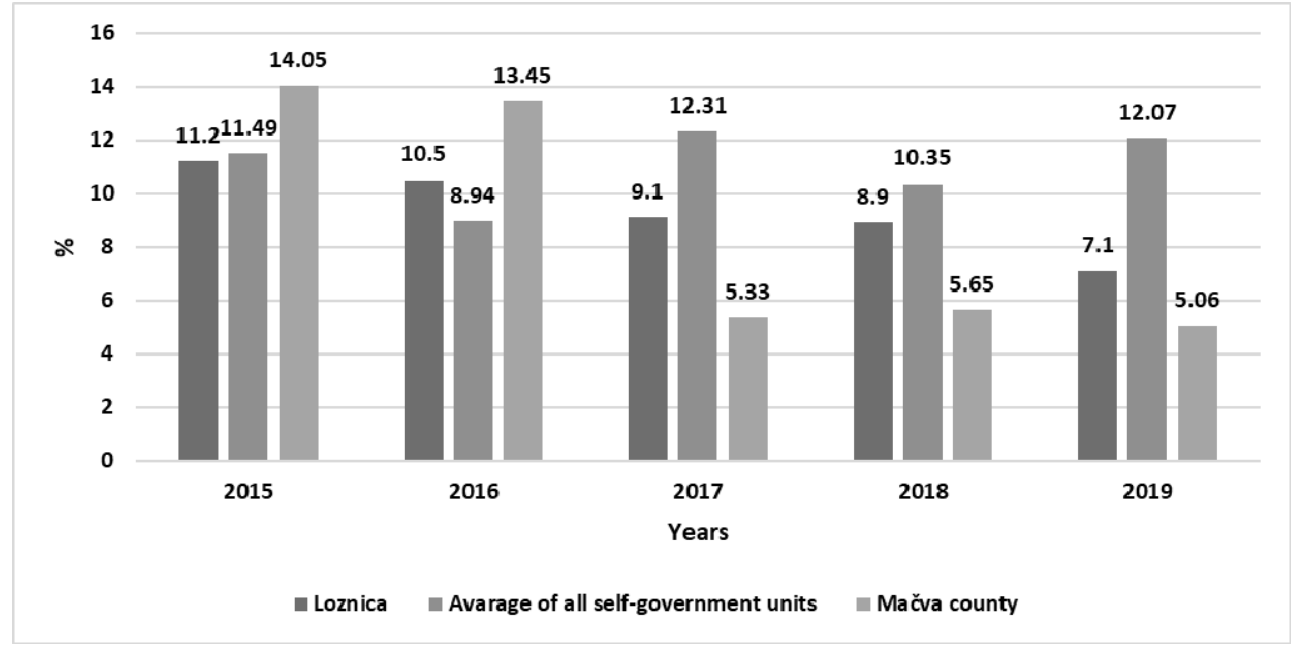

Source: the author's calculation and layout based on the data of the Republic Secretariat for Public Policy

The indicator represents the ability of an entity to settle its credit liabilities from its own resources. It should be less than 5 , which clearly means that public utility companies can settle their liabilities from their own resources in 5 years. (Long-term liabilities + shortterm liabilities - cash equivalents and cash) / (Profit before tax + Interest expenses (to third parties) + depreciation costs). Net debt / EBITDA ratio measures the ratio of a loan taken that is not covered by cash and marketable securities of the company and equity. Net debt shows the level of debt at which a company remains burdened after all liabilities have been disbursed using liquid assets (Wiehle, Diedelmann, Deter, Schomig \& Rolf, 2006). The lower the value of this indicator, the more the financial security and stability of an enterprise. Higher value represents a higher degree of indebtedness and lower coverage of this debt by enterprises liquid assets. The negative value of the indicator indicates the low total indebtedness covered by the company's liquid assets. The aim of calculating this indicator is to consider the level of net debt of public companies from the territory of the city of Loznica in relation to the average of other municipalities. The value of stated indicator was below the average of public entities of all units of self-government in 4 out of observed 5 years. By observing the whole period, public utility companies on the territory of the city of Loznica can settle their liabilities from their own sources in the period of 9.3 years. Declining trend over the years represents a positive phenomenon. 


\section{Conclusion}

Prior to drawing the conclusions, it is necessary to stress that each economic and financial analysis has its own flaws. According to Chondhry, 2006, the most important limitations in the implementation of ratio analysis are: various accounting techniques can call into questions the comparison of values of certain ratio, that is, it can be a problem caused by inflation that affects financial reports (depreciation of values of many positions in financial reports) negatively; certain entities are decentralized or divisionally structured, which makes it difficult to calculate branch average as a basis for comparison; a certain number of companies want to have better indicators than the branch average, so that linking to average indicators of ratio analysis does not always have to be a good comparison; when of comparing the same ratios in the same company, changes and circumstances that can occur in the period of observed analysis can be taken into account; in the case of analysis, there occurs a dilemma on which ratio is acceptable and which is not. Based on the results of carried out research it could be noticed that the problem is with high indebtedness of public utility company "Water Supply and Sewerage" and public utility company "Heating Plant". The reason for high indebtedness of public utility company "Water Supply and Sewerage" lies in credit indebtedness of the company in 2008, the repayment of which will last for the next 4 years. Unlike this company, high debts of public utility company "Heating Plant" are the reason for "tails" that the company entails from the previous period and are linked to unsettling liabilities based on obtained gas. Accordingly, more detailed analysis of the business operations of this entity is needed, including and analysing business operations of the entity in a longer period of time. The remaining three observed entities, based on the values of obtained indebtedness indicators, do not have major problems with total liabilities. When analysing indicators, which, when calculated, take into account the value of the basic and their own capital at the disposal of observed public entities, attention should be paid to the report of an independent auditor (from 2017 to 2019). The auditing report points to mismatch of the value of the entity's basic capital and the value enlisted in the Business Registers Agency, stressing that the real value of all three entities is significantly above this one enlisted in the Business Registers Agency. Besides the analysed indebtedness and shown problems with the view of values of these indicators with the majority of public utility companies in Serbia, each of the analysed companies is facing other specific problems arising from the nature of their field of activity and from inherited difficult situation (technical and technological obsolescence, irrational consumption, high budget dependence, many companies oversized, staff issues etc.).

\section{References}

Agencija za privredne registre. Retrieved 01/04/2021 from: https://pretraga2.apr.gov.rs/unifiedentitysearch

Atrill, P. (2006). Financial management for decision makers. Harlow: Pearsons education Limited.

Bernstein, L. A., \& Wild, J. J. (1999). Analysis of financial statements. New York: McGraw-Hill. 
Bernstein, L. A., \& Wild, J. J. (1999). Analysis of financial statements. New York: McGraw-Hill

Brealey R., Myers S., \& Allen F. (2010). Principless of Corporate Finance, Global edition, New York: McGraw- Hill/Irwin.

Choundy, M. (2006). An Introduction to Bond Markets. New Jersey: John Wiley \& Sons.

Damodaran, A. (2001).Corporate Finance: Theory and Practice. New York: John Wiley.

Domanović, V. (2013). Efektivnost sistema merenja performansi u uslovima savremenog okruženja, Ekonomski horiznosti, 15(1), 31-44. Doi: https://doi.org/10.5937/ekonhor1301031D

Elia, M. (2006).Microfinance: Text and Cases. Torino: Università degli Studi di Torino, SAA.

Elliott, B., \& Elliott, J. (2006). Financial Accounting, Reporting and Analysis. Harlow: Pearson Education Limited.

Elliott, B., \& Elliott, J. (2006). Financial Accounting, Reporting and Analysis. Harlow: Pearson Education Limited.

Erić, D. (1992). Struktura kapitala i strategijsko upravljanje. Beograd: Ekonomski fakultet.

Erić, D. (2003). Finansijska tržišta i instrumenti, 2. Izdanje. Beograd: Čigoja štampa.

Erić, D., Beraha, I., \& Đuričin, S. (2011). Financing innovative small and medium-sized enterprises in times of crisis, Romanian Journal of Economics, 33, 59-74.

Evans, M. (2000). Course 1: Evaluating Financial Performance. Retrieved April 20, 2012, from Excellence in Financial Management: http://www.exinfm.com/training/pdfiles/course01.pdf

Fabozzi, F. J., \& Peterson, P. P. (2003). Financial Management and Analysis. Hoboken, New Jersey: John Wiley \& Sons, Inc.

Fleisher S. C., \& Bensoussan E.B. (2000). A FAROUT way to manage CI analysis, Competitive Intelligence Magazine, 3(2), 37-40.

Hagos, T., \& Pal, G. (2010). The means of analysis and evaluation for corporate performances. Annales Universitatis Apulensis Series Oeconomica, 12(1), 438-449.

Helfert, E. (2001). Financial Analysis Tools and Techniques: a Guide for Managers. New York: McGraw-Hill.

Horne, C.J., \& Washowicz M.J. (2007). Osnovi finansijskog menadžmenta, prevod. Beograd: Data Status.

Kaplan, R. S., \& Anderson, S. R. (2007). The Evolution od Time - Driven Activity - Based Costing: Introduction u Time - Driven Activity Based Costing. Boston: HBSP.

Kaplan, R. S., \& Norton, D. P. (1996). Linking the balanced scorecard to strategy. California Management Review, 39(1), 53-79. Doi: https://doi.org/10.2307\%2F41165876 
Kothari, J., \& Barone, E. (2012). Finansijsko računovodstvo - međunarodni pristup, prevod. Beograd: Data Status.

Marr, B. (2012). Key Performance Indicators: the 75 Measures Every Manager Needs to Know. Hampshire: Pearson Education Ltd.

Mishkin F.S. \& Eakins S.G. (2006).Financial Markets and Institutions, 6th edition. Boston: Pearson - Addison Wesley.

Neely, A., Gregory. M., \& Platts, K. (1995). Performance measurement system design: a literature review and research agenda. International Journal of Operations and Production Management, 15(4), 80-116. Doi: https://doi.org/10.1108/01443579510083622

Palepu, K., Healy, P., \& Bernard, V. (2004). Business Analysis and Valuation Using Financial Statements - Text and Cases. McGraw Hill.

Republički sekretarijat za javne politike. Retrived 10/04/2021 from: https://rsjp.gov.rs/cir/analiticki-servis/

Rodić J., Andrić M., Vukelić G., \& Vuković B., (2017). Analiza finansijskih izveštaja. Beograd: Ekonomski fakultet.

Savich, R., \& Thompson, L. (1978). Resource allocation within the product life cycle. MSU Business Topics, 35-44.

Savich, R., \& Thompson, L. (1978). Resource Allocation Within the Product Life Cycle. MSU Business Topics, 35-44.

Selling, T. I., \& Stickney, C. P. (1989). The effects of business environment and strategy on a firm's rate of return on assets. Financial Analysts Journal, 45(1), 43-52. Doi: https://doi.org/10.2469/faj.v45.n1.43

Shim, J. K. (2008). Analysis and Uses of Financial Statements. London: Global Professional Publishing Limited.

Stead, M. (1995). How to Use Company Accounts for Successful Investment Decisions. FT Pitman Publishing.

Walsh, C. (2008). Key Management Ratios: the 100+ Ratios Every Manager Needs to Know. Pearson Education Ltd.

White, G. I., Sondhi, A. C., \& Fried, D. (2003). The Analyses and Use of Financial Statements. John Wiley \& Sons, Inc.

Wiehle, U., Diedelmann, M., Deter, H., Schomig, P., \& Rolf, M. (2006). 100 IFRS Financial Ratios. Wiesbaden: Cometis AG. 